\title{
PENGEMBANGAN MEDIA BOARD GAME ULAR TANGGA PADA MATERI METAMORFOSIS KUPU-KUPU TEMA 3 SUBTEMA 2 KELAS IV SDN 169 PEKANBARU
}

\author{
Uswatun Hidayah $^{1}$, Siti Quratul Ain ${ }^{1}$ \\ ${ }^{1}$ Universitas Islam Riau, Pekanbaru \\ *Corresponding Address: uswatunhidayah02@gmail.com
}

Naskah diterima: 11 September 2021| Disetujui: 29 September 2021 | Diterbitkan: 2 Oktober 2021

\begin{abstract}
Abstarct: Learning media is one of the learning components that is needed when carrying out learning, to support a learning goal. The use of learning media should be a very important part of an educator as a facilitator of learning activities. The purpose of this research is to develop learning media for snakes and ladders board game on theme 3 sub-theme 2 in class IV that is valid. The learning model used by the researcher is the ADDIE model (Analysis, Design, Development, Implementation, and Evaluation). The research carried out by researchers only reached the 3rd stage, namely development due to the covid-19 pandemic. Techniques and data collection instruments used in the study were documentation and validation from media and material experts. The data analysis technique used in this research is quantitative and qualitative data analysis techniques. The results by the media obtained a value of $97.5 \%$ with a very valid category while the validation by material experts obtained a value of $95.29 \%$ with a very valid category. So it can be said that the board game learning media is valid for use in learning the butterfly metamorphosis theme 3 subtheme 2 class IV material.
\end{abstract}

Keywords: Development, Media, board game, metamorphosis

\begin{abstract}
Abstrak: Media pembelajaran merupakan salah satu komponen belajar yang sangat diperlukan saat melaksanakan pembelajaran untuk menunjang tujuan pembelajaran. Pemanfaatan media pembelajaran seharusnya menjadi bagian yang sangat diperhatikan oleh seorang pendidik sebagai fasilitator kegiatan pembelajaran. Tujuan penelitian mengembangkan media pembelajaran board game ular tangga pada tema 3 subtema 2 di kelas IV yang valid. Model pembelajaran yang digunakan peneliti yaitu model ADDIE (Analysis, Design, Development Implementasi, dan Evaluation). Penelitian yang dilakukan peneliti hanya sampai tahap ke-3 yaitu development karena adanya pandemi covid-19. Teknik dan instrumen pengumpulan data yang digunakan pada penelitian adalah dokumentasi dan lembar validasi dari ahli media dan materi. Teknik analisis data yang digunakan pada penelitian ini adalah teknik analisis data kuantitatif dan kualitatif. Hasil validasi oleh media memperoleh nilai sebesar 97,5\% dengan kategori sangat valid, sedangkan validasi oleh ahli materi memperoleh nilai sebesar 95,29\% dengan kategori sangat valid. Maka dapat disimpulkan bahwa media pembelajaran board game valid untuk digunakan pada pembelajaran materi metamorfosis kupu-kupu tema 3 subtema 2 kelas IV.
\end{abstract}

Kata kunci: Pengembangan, Media, board game, metamorphosis 


\section{PENDAHULUAN}

Pentingnya memilih penggunaan media pembelajaran yang tepat pada saat pembelajaran yang berlangsung antara tenaga pendidik dan peserta didik merupakan hal yang penting, sebab dengan media pembelajaran yang menarik perhatian peserta didik mereka akan mendapat pembelajaran yang bermakna dalam belajar sehingga materi yang akan disampaikan akan mudah dipahami oleh peserta didik, sehingga tujuan pembelajaran akan tercapai. Media pembelajaran merupakan alat, bahan, yang digunakan sebagai penyampaian pesan dalam proses pembelajaran (Atiaturrahmaniah, 2017). Lebih lanjut media merupakan sarana penyalur atau informasi belajar yang hendak disampaikan oleh sumber pesan kepada sasaran atau penerima pesan tersebut. Media dapat dikatakan juga alat untuk menyampaikan pesan isi materi pembelajaran yang disampaikan ke peserta didik yang dapat merangsang pemikiran siswa dalam proses pembelajaran agar berjalan lebih efektif. Kata media berasal dari bahasa latin medius yang secara harfiah berarati "tengah", "parantara", atau "pengantar", dengan demikian dapat diartikan bahwa media merupakan wahana penyalur informasi belajar atau penyalur belajar (Arsyad, 2014).

Penggunaan media pembelajaran sangatlah menunjang proses belajar siswa, tetapi tetap saja diperlukan keterampilan guru dalam memilih media yang akan digunakan unruk proses belajar dengan menyesuaikan keadaan dan kondisi peserta didik, yakni media yang dapat membangkitkan semangat siswa belajar dan aktif serta keikut sertaan proses pembelajaran. Penggunaan media dapat disesuaikan materi apa yang akan diajarkan pada pembelajaran. Media pembelajaran merupakan salah satu komponen belajar yang sangat diperlukan saat melaksanakan pembelajaran, demi menunjang suatu tujuan pembelajaran. Pemanfaatan media pembelajaran seharusnya menjadi bagian yang sangat diperhatikan oleh seorang pendidik sebagai fasilitator kegiatan pembelajaran. Dengan demikian setiap pendidik memerlukan media pembelajaran yang efektif agar dapat mencapai tujuan pembelajaran.

Tujuan media pembelajaran adalah untuk membantu jalannya proses pembelajaran menjadi lebih efektif dan efesien. Tujuan media pembelajaran yaitu: 1) Mempermudah proses pembelajaran didalam kelas, 2) Meningkatkan efesiesi prises pembelajaran, 3) Menjaga relevansi anatara materi pemlajaran dengan tujuan belajar, 4) Membantu konsentrasi siswa dalam proses pembelajaran (Suryani, 2018). Adapun tujuan media pembelajaran yaitu "digunakan untuk membantu guru dalam menyampaikan materi kepada siswa agar materi mudah disampaikan dan mudah untuk dipahami siswa" (Alfasyi, 2015). Berdasarkan pendapat para ahli diatas tujuan media pembelajaran yaitu untuk mempermudah guru dalam menyampaikan suatu materi pembelajaran dan memudahkan siswa dalam menerima pembelajaran serta memudahkan tujuan pembelajaran itu tercapai. 
Media diklasifikasikan ke dalam beberapa kelompok, yaitu 1) media berbasis manusia (guru, instruktur, turor, main-peran, kegiatan kelompok, field-tripe), 2) media berbasis cetak (buku, penuntun, buku latihan (workbook), alat bantu kerja, dan lembaran lepas, 3) media berbasis visual (buku, alat bantu kerja, bagan, grafik peta, gambar, transparasi, slide), 4) media berbasis audio-visual (video,film, progam slide-tape, televisi), 5) media berbasis komputer (pengajaran dengan bantuan computer, interaktif video hypertext) (Arsyad, 2014), yang terpenting media dipersiapkan untuk kebutuhan dan kamampuan belajar agar siswa aktif sealama proses belajar. Dengan demikian pentingnya media pembelajaran saat belajar sangat membantu proses belajar siswa menjadi lebih mengikuti pembelajaran dan bisa ikut berpartisipasi, penggunaan media pun harus tepat dilihat dari materi yang akan diajarkan agar lebih efektif, contohnya saja media board game ular tangga atau dapat disebut media visual.

Dalam rangka mewujudkan suasana pembelajaran aktif, inovatif, kreatif, dan menyenangkan sesuai dengan standar proses pendidikan, guru dituntut untuk menggunakan berbagai macam media pembelajaran. Tujuan dari mengembangkan kreativitas adalah agar dapat mengekspresikan diri melalui hasil karya baru yang dapat digunakan sebagai alternatif pemecahan masalah (Mustika, 2020). Media pembelajaran yang membuat siswa tidak cepat bosan salah satunya media board game ular tangga. Media board game ular tangga merupakan jenis media yang menggunakan papan permainan board game, yaitu permainan yang melibatkan bidak yang dipindahkan atau ditempatkan pada permukaan atau papan "yang sebelumnya sudah ditandai” (Huang dalam Simanjuntak, 2019), sesuai dengan aturan yang ditetapkan sebelumnya. Salah satu board game yang diketahui oleh seluruh masyarakat yaitu permainan catur. Sedangkan menurut Fukuda (Simanjuntak, 2019) dalam catur, potongan-potongan yang meniru komandan dan prajurit dari tentara, dan mereka pertempuran dipapan dengan menggerakkan mereka. Ular tangga merupakan permainan papan atau kertas yang dimainkan dua orang atau bisa lebih. Papan permainan dibagi dalam kotak-kotak kecil didalamnya terdapat gambar "ular" dan "tangga" yang menghubungkan kekotak lainnya (Musa'adah, 2017). Menurut Melsi (dalam Setiawati, 2019) ular tangga merupakan permaianan papan untuk anak-anak yang dimainkan oleh 2 orang atau lebih. Papan permainan dibagi dalam kotak-kotak kecil dan beberapa kotak di gambar sejumlah "tangga" atau "ular" yang menghubungkan kotak lainnya. Sedangkan menurut Husna menyatakan bahwa ular tangga merupakan permainan yang menggunakan dadu untuk menentukan beberapa langkah yang harus dijalani bidak (Safitri, 2019). Permaian ini termasuk dalam kategori "board game” atau permainan papa sejenis dengan monopoli, halma, ludo, dan sebaginya. Sadiman berpendapat setiap kontes antara para pemain yang berinteraksi satu sama lain dengan mengikuti aturan-aturan tertentu untuk mencapai tujuan-tujuan tertentu pula (Karimah, 2014) 
Media board game ular tangga memiliki beberapa kelebihan dan kelemahan. Kelebihan dari media board game ular tangga tangga, diantaranya 1) Siswa belajar sambil bermain, 2) Siswa tidak belajar sendiri, 3) Memudahkan siswa belajar karena dibantu dengan gambar yang ada didalam permaianan ular tangga, 4) Tidak memerlukan biaya mahal dala pembuatan media pembelajaran (Afandi, 2015). Sedangkan kelemahan pada media board game ular tangga antara lain 1) Membutuhkan persiapan yang matang agar menyesuaikan konsep materi kegiatan pembelajaran, 2) Jika terdapat siswa yang cepat bosan makan ia akan kehilangan minat untuk bermain, 3) Penggunaan media permaianan ular tangga memerlukan banyak waktu untuk menjelaskan kepada anak-anak, 4) Permaianan ular tangga tidak dapat menggembangkan semua materi pembelajaran, 5) Kurangnya pemahaman aturan permainan oleh anak akan dapat menimbulkan kericuhan, 6) Jika siswa turun tangga maka kemungkinan mendapatkan jenis soal yang sama (Desri, 2019).

Permainan adalah modal awal bagi pembinaan awal kecerdasan dan mental-emosional anak, sehingga cara dan pola bermain yang diterapkan dalam pembelajaran akan memiliki efek positif bagi pertumbuhan kecerdasan dan emosional. Hal itu karena penggunaan strategi bermain dengan bantuan alat permainan edukatif ditujukan untuk mengembangkan tiga kemampuan pokok, yaitu; 1) Kemampuan fisik-motorik (psikomotor), dengan bergerak, seperti berlari, melompat dan lain-lain; 2) Kemampuan sosial emosional (afektif), merupakan aktivitas bermain dikarenakan anak senang untuk melakukannya; 3) Kemampuan kecerdasan (kognisi), dimana anak dalam proses bermain diperkenalkan dengan berbagai informasi dan pengetahuan seperti perbendaharaan huruf, angka, kata, bahasa, komunikasi timbal balik (Suyadi, 2017). Permainan dapat membantu suasana lingkungan belajar menjadi senang, bahagia, santai, namun tetap memiliki suasana belajar yang kondusif (Septiria, 2020). Dengan bermain, banyak kemampuan/keterampilan dapat dipraktekkan secara berulang-ulang, sehingga bisa dikuasai dengan baik. Permainan ini menuntut kecermatan setiap langkah agar mencapai finish. Dengan menggembangkan media ular tangga siswa dapat belajar lenih aktif kreatif sehingga materi pelajaran yang di ajarkan dipahami secara mendalam.

Berdasarkan hasil wawancara yang dilakukan oleh peneliti pada guru kelas Ivsekolah Dasar Negeri 169 Pekanbaru yang berada di Jalan Merpati Raya No. 03 Komplek Perumnas Griya Nusantara Perhentian Marpoyan, Maharatu, Kec Marpoyan Damai didapati bahwa penggunaan media masih kurang maksimal. Sehingga kegiatan pembelajaran dikelas ditemukan beberapa permasalahan, yaitu terbatasnya media yang digunakan dalam proses pembelajaran, kurangnya semangat siswa tentang metamorphosis. Dibuktikan dengan menurunnya hasil belajar siswa yang tidak sesuai KKM yang pada pada semester dua mencapai $65 \%$. Dengan begitu pendidik memerlukan media yang efektif dalam materi metamorphosis kupu-kupu sahingga siswa dapat memahami materi tersebut. 
Berdasarkan permasalahan diatas peneliti akan mengembangkan media yang dapat membantu guru dalam proses pembelajaran sehingga dapat membantu siswa semangat dalam belajar pada materi metamorphosis kupu-kupu tema 3 subtema 2 pembelajaran di kelas IV Sekolah Dasar Negeri 169 Pekanbaru. Media yang akan dikembangkan yaitu media board game ular tangga. Media board game ular tangga ini termasuk media visual yang mana media yang menggunakan gambar sehingga siswa lebih tertarik dan siswa dapat memahami dengan baik dengan bantuan media tersebut. Berdasarkan uraian di atas, maka penulis melakukan penelitian dengan judul penelitian pengembangan media board game ular tangga pada materi metamorfosis kupu-kupu tema 3 subtema 2 kelas IV Sekolah Dasar Negeri 169 Pekanbaru.

\section{METODE}

Jenis penelitian yang digunakan yaitu penelitian pengembangan yaitu pengembangan. Penelitian pengembangan merupakan metode penelitian yang diterapkan untuk memperoleh suatu hasil produk (sugiyono, 2019). Sedangkan Ibnu memberikan pengertian tentang penelitian pengembangan sebagai jenis penelitaian yang ditunjukan untuk menghasilkan suatu produk hardware atau software melalui prosedur yang khas yang biasanya diawali dengan need assessment, atau analisis kebutuhan, dilanjut dengan proses pengembangan dan diakhiri dengan evaluasi (Purnama, 2013). Dari beberapa pengertian di atas dapat disimpulkan bahwa pengertian penelitian pengembangan merupakan suati jenis penelitian yang bertujuan menghasilkan produk-produk agar tujuan pembelajaran dapat tercapai.

Model pembelajaran yang digunakan peneliti yaitu model ADDIE (Analysis, Design, Development Implementasi, dan Evaluation). Produk media pembelajaran yang akan dihasilkan dari penelitian dan pengembangan ini adalah media pembelajaran board game ular tangga pada materi metamorphosis kupu-kupu tema 3 subtema 2 di kelas IV. Penelitian yang dilakukan peneliti yang membatasi tahap model ADDIE sampai tahap ke-3 yaitu development sedangkan tahapan implementasi dan evaluation tidak dapat dilaksanakan karena sekarang masih masa pandemic covid19. Adapun langkah-langkah yang digunakan yaitu analysis, design, dan development.

Tahap awal yang dilakukan peneliti adalah analisis, merupakan tahap pengumpulan data dengan mengidentifikasi permasalahan SDN 169 Pekanbaru. Peneliti melaksanakan analisis mencakup tiga hal, yaitu analisis kurikulum, analisis kebutuhan, dan analisis materi, (1) Analisis kurikulum yaitu dengan mengenali KI dan KD pada kurikulum 2013. Tujuan tahap ini untuk menentukan materi yang digunakan dalam media board game ular tangga. Dimana penelitian ini memilih materi mengenai metamorfosis kupu-kupu, (2) Analisis kebutuhan ini untuk mengetahui masalah yang ada di sekolah 
terkait media pembelajaran yang digunakan dalam kegiatan proses pembelajaran pada materi metamorphosis kupu-kupu sehingga dibutuhkan pengembangan media board game ular tangga, (3) Analisis materi untuk menentukan materi yang harus dipelajari pada metamorphosis kupu-kupu dan menentukan indikator yang sesuai dengan kurikulum 2013.

Selanjutnya tahap desain, ini bertujuan untuk mendesain terhadap produk media board game ular tangga tema 3 subtema 2 dengan membuat sketsa tabel dan kolom yang biasanya terdapat pada permainan ular tangga lalu disusun dengan menyesuaikan kompetensi dasar dan indicator yang diturunkan menjadi tujuan pembelajaran yang akan dirancang menjadi media pembelajaran. Dalam desain ini meliputi cover, kompetensi dasar, tujuan pembelajaran, isi materi serta terdapat contohcontoh soal dalam media board game ular tangga yang dikembangkan dengan kemasan yang menarik agar dapat menarik perhatian siswa dalam proses pembelajaran.

Tahap pengembangan, dalam tahap pengembangan ini merupakan produksi dari media board game ular tangga yang telah di desain atau di rancang pada tahap kedua. Proses pengembangan media board game ular yang akan diproduksi oleh peneliti adalah sebagai berikut:

a. Siapkan alat dan bahan yang akan digunakan pada media board game ular tangga.

b. Setelah terkumpul alat dan bahan yang akan dijadikan media, yang pertama dilakukan yaitu membuat kolom sebanyak 30 nomor.

c. Berikanlah warna pada setiap kolom yang berbeda.

d. Memberikan gambar seperti ular, bintang, dan tangga untuk instruksi pada ular tangga tersebut.

e. Berikanlah gambar-gambar untuk memberikan yang baik pada siswa.

f. Siapkan kertas untuk menulis apa pelanggaran apabila siswa tidak bisa menjawab pertanyaan.

g. Membuat pertanyaan pada kertas lain, yang mana pertanyaan tersebut akan digunakan sesuai dengan nomor.

h. Membuat dadu dari kertas dan berikan angka pada setiap sisinya dari angaka 1 sampai 6 .

i. Lalu media board game ular tangga siap untuk digunakan.

Peneliti juga melakukan uji validitas dengan tujuan untuk mengetahui kekurangan dan kesalahan pada produk media sehingga dapat menjadi valid untuk digunakan pada proses pembelajaran. Media yang dikembangkan terlebih dahulu divalidasi oleh validator ahli media dan ahli materi. Adapun nama-nama validator yaitu ahli media adalah Ivan Taufiq, M. I. Kom. dan Benni Handayani, M. I. Kom. selanjutnya ahli materi adalah Exmela Dona, S. Pd. dan Jannah Sulaiman, S. Pd. penelitian ini menggunakan model ADDIE yang terdiri atas lima tahap yaitu analisis, desain, pengembangan, implementasi, dan evaluasi. Pada penelitian ini dalam mengembangkan media boar 
game ular tangga dilakukan beberapa tahapan sesuai dengan kebutuhan penelitian. Penelitian ini hanya melakukan tahapan analisis, desain, dan pengembangan. Hal ini dilakukan karena masih pada masa pandemi covid-19, sehingga tahapan implementasi dan evaluasi tidak dapat dilaksanakan.

Jenis data yang akan diperoleh dari penelitian ini berupa data primer dan data sekunder. Adapun data primer adalah data yang dikumpulkan oleh peneliti secara langsung dari sumber datanya. Teknik yang dapat digunakan peneliti untuk mengumpulkan data primer adalah wawancara, validator, ahli media dan validator ahli materi serta data dari guru kelas IV SDN 169 Pekanbaru. Adapun data sekunder adalah data yang dikumpulkan peneliti dari sumber yang telah ada. Pada penelitian ini data sekunder dapat dari buku, jurnal serta skripsi yang berkaitan dengan pengembangan.

Teknik analisis data yang digunakan pada penilitian ini adalah teknik analisis data kuantitatif dan analisis data kualitatif. Data kualitatif diperoleh dari saran dan komentar validasi yang telah diisi oleh validator ahli media dan validator ahli materi. Data kuantitatif diperoleh dari hasil penilaian validasi yang sudah diisi serta responden guru. Data hasil penelitian terhadap kelayakan produk pengembangan media pembelajaran dianalisis secara deskriptif. Untuk menghitung persentase kevalidan media pembelajaran, Data validasi dapat dihitung dengan menggunakan rumus (Akbar, 2013).

$$
\begin{aligned}
& \mathrm{Va} 1=\frac{T S e}{T S h} \times 100 \% \\
& \mathrm{Va} 2=\frac{T S e}{T S h} \times 100 \% \\
& \mathrm{Va}_{3}=\frac{T S e}{T S h} \times 100 \%
\end{aligned}
$$

Sumber: (Akbar, 2013)

Untuk memperoleh kesimpulan peneliti menggunakan analisis gabungan dapat dirumuskan sebagai berikut:

$$
\mathrm{V}=\frac{V a 1+V a 2+V a 3}{3}
$$

Keterangan:

$$
\begin{array}{ll}
\text { V } & \text { : Validasi (gabungan) } \\
\text { Va1 } & \text { : Validasi Ahlli ke-1 } \\
\text { Va2 } & \text { : Validasi Ahli ke-2 } \\
\text { Va3 } & \text { : Validasi Ahli ke-3 } \\
\text { Tsh } & \text { : Total skor maksimal yang diharapkan } \\
\text { Tse } & \text { : Total skor empiris ( hasil validasi dari validator) }
\end{array}
$$


PENGEMBANGAN MEDIA BOARD GAME ULAR TANGGA PADA MATERI METAMORFOSIS ...

Uswatun Hidayah, Siti Quratul Ain

Penentuan tingkat validitas produk media pembelajaran dapat dilihat pada tabel sebagai berikut:

Tabel 1. Tingkat Kevalidan dan Revisi Produk

\begin{tabular}{ccc}
\hline No & Kriteria & \\
\hline 1. & $85,01 \%-100,00 \%$ & Sangat valid atau dapat digunakan \\
2. & $70,01 \%-85,00 \%$ & Cukup valid atau dapat digunakan namun perlu direvisi kecil \\
3. & $50,01 \%-70,00 \%$ & Kurang valid, disarankan tidak dipergunakan karena perlu revisi besar \\
4. & $01,00 \%-50,00 \%$ & Tidak valid, atau tidak boleh dipergunakan
\end{tabular}

sumber: (Akbar, 2013)

Berdasarkan tabel tersebut, sebuah media dapat dikatakan valid jika tingkat kevalidan yang telah dicapai paling rendah adalah valid.

\section{HASIL DAN PEMBAHASAN}

Penelitian yang telah dilakukan merupakan penelitian jenis pengembangan, yaitu pengembangan media board game ular tangga pada materi metamorfosis kupu-kupu siswa kekas IV SDN 169 Pekanbaru. Penelitian pengembangan ini dilakukan selama 3 bulan, dihitung dari awal proses penelitian sampai media board game ular tangga dinyatakan valid oleh ahli media dan ahli materi. Adapun proses awal yang harus dilewati yaitu dengan menentukan tempat dan subjek penelitian. Selanjutnya dilakukan kegiatan wawancara dengan guru kelas IVA SDN 169 Pekanbaru. Untuk mengetahui kebutuhan aspek media pembelajaran yang digunakan, kurikulum, dan materi terkait dengan penelitian yang dilakukan. Selanjutnya peneliti membuat produk media board game ular tangga tema 3 subtema 2. Media ini juga menggunakan alat penunjang lain, seperti kertas pertanyaan dengan memuat soal-soal yang berhubungan dengan materi pembelajaran untuk diberikan pada siswa.

Media yang dikembangkan terlebih dahulu divalidasi dari tim yang telah ahli di bidangnya yaitu terdiri dari validator ahli media dan ahli materi. Adapun nama-nama validator yaitu ahli media adalah Ivan Taufiq, M. I. Kom. selaku Dosen Fakultas Ilmu Komunikasi Universitas Islam Riau dan Benni Handayani, M. I. Kom. selaku Dosen Fakultas Ilmu Komunikasi Universitas Islam Riau, selanjutnya ahli materi adalah Exmela Dona, S. Pd. selaku kepala sekolah di Sekolah Dasar Negeri 104 Pekanbaru dan Jannah Sulaiman, S. Pd. guru kelas IV di Sekolah Dasar Negeri 169 Pekanbaru. Penelitian ini menggunakan metode ADDIE yang terdiri atas lima tahap yaitu analisis, desain, pengembangan, implementasi, dan evaluasi. Pada penelitian ini dalam mengembangkan media board 
game ular tangga dilakukan beberapa tahapan sesuai dengan kebutuhan penelitian. Penelitian ini hanya melakukan tahapan analisis, desain, dan pengembangan. Hal ini dilakukan karena masih pada masa pandemi covid-19, sehingga tahapan implementasi dan evaluasi tidak dapat dilaksanakan.

Tahap awal yang dilaksanakan adalah analisis merupakan tahap pengumpulan data dengan mengidentifikasi permasalahan di Sekolah Dasar Negeri 169 Pekanbaru. Tahapan analisis yang dilakukan peneliti mencakup tiga hal, yaitu analisis kurikulum, analisis kebutuhan, dan analisis materi. Pada proses analisis kurikulum dengan mengenai Kompetensi Inti dan Kompetensi Dasar pada kurikulum 2013. Tujuan tahap ini untuk menentukan materi yang digunakan dalam media pembelajaran board game ular tangga. Dimana peneliti materi mengenai metamorfosis kupu-kupu. Hal ini mencakup kompetensi dasar dan indikator-indikator pencapaian kompetensi yang mengacu pada kurikulum 2013. Adapun KD dan indikator yang akan dianalisis peneliti adalah sebagai berikut: Kompetensi dasar

3.1 menganalisis hubungan antara bentuk dan fungsi pada tubuh hewan Indikator

3.1.1 menunjukkan bagimana bentuk-bentuk hewan

\subsection{1 memahami kehidupan serta bentuk dan fungsi tubuh hewan}

Proses selanjutnya adalah analisis kebutuhan ini dilakukan dengan melakukan kegiatan wawancara dengan guru kelas IVA untuk mengetahui masalah yang terdapat di kelas IV terkait media pembelajaran yang digunakan dalam kegiatan proses pembelajaran ilmu pengetahuan alam (IPA). Media pembelajaran yang digunakan guru yaitu media gambar. Adapun media gambar yang biasa digunakan guru sebagai berikut.

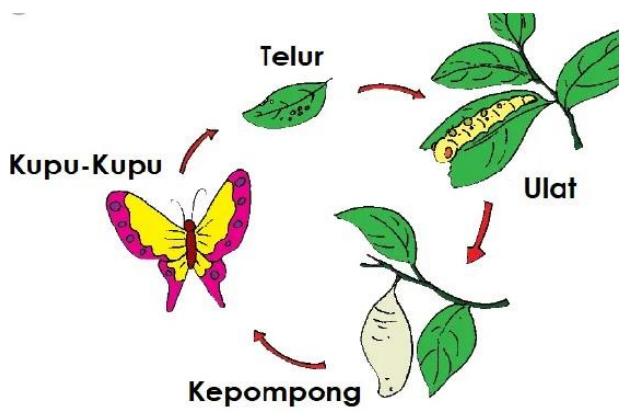

Gambar 1. Media yang digunakan

Berdasarkan media tersebut membuat siswa yang duduknya paling belakang tidak terlalu jelas dengan media gambar yang digunakan oleh guru dan kurang menarik. Sementara sarana yang ada di sekolah sudah cukup memadai untuk menunjang kegiatan pembelajaran. Guru bisa memanfaatkan 
fasilitas yang ada untuk menghasilkan media pembelajaran yang lebih menarik, kreatif dan mampu memotivasi siswa saat pembelajaran. Berdasarkan permasalahan di atas sehingga peneliti berinisiatif untuk membuat media board game ular tangga untuk menciptakan pembelajaran yang menarik dengan tujuan agar siswa mendapatkan proses pembelajaran yang bermakna sehingga materi yang diajarkan akan mudah dipahami oleh siswa.

Analisis terakhir yang dilakukan adalah analisis siswa, untuk mengetahui respon siswa terhadap media pembelajaran yang digunakan oleh guru yaitu media gambar. Berdasarkan hasil wawancara yang dilakukan pada tanggal 28 Januari 2021 banyak siswa menganggap pembelajaran IPA sulit dipahami sehingga dalam proses pembelajaran banyak siswa yang kurang tertarik dan kurang antusis untuk mengikuti kegiatan pembelajaran dan menyebabkan hasil belajar dan siswa kurang semangat karena tingkat belajarnya kurang maksimal serta kurang mengerti pada pelajaran IPA materi metamorfosis kupu-kupu, walaupun guru sudah menggunakan media pembelajaran, namun guru sudah berusaha membangun suasana belajar yang menyenangkan dan membuat siswa berusaha memahami materi metamorfosis kupu-kupu dengan menggunakan media gambar. Media gambar yang digunakan kurang terlihat jelas oleh siswa yang duduk kursi paling belakang sehingga siswa kurang memperhatikan media yang ditampilkan oleh guru.

Langkah selanjutnya adalah desain, pada langkah ini menjelaskan mengenai rancangan media pembelajaran board game ular tangga dengan tema 3 subtema 2 pada mata pelajaran IPA pada materi metamorfosis kupu-kupu yang mana peneliti akan menggunakan media cetak. Dengan begitu peneliti akan memasukkan materi metamorfosis kupu-kupu menggunakan media cetak tersebut, dengan begitu peneliti mendesain media cetak tersebut dengan semenarik mungkin dengan menggunakan tema berdasarkan materi yaitu kupu-kupu. Kemudian dilanjutkan pada bagian proses pembuatan media board game ular tangga. Adapun proses pembuatan produk media board game ular tangga, yaitu (1) peneliti mendesain media ular tangga sesuai temanya yaitu metamorfosis kupu-kupu menggunakan laptop, (2) membuat pertanyaan sebanyak nomor yang ada di kotak ular tangga tentang metamorfosis kupu-kupu, (3) menambahkan gambar-gampang tentang kupu-kupu, (4) menyediakan alat penunjang lainnya seperti kertas pertanyaan dan dadu yang akan digunakan saat bermain.

Tahap berikutnya adalah pengembangan, tahap ini merupakan tahap pengembangan media board game ular tangga pada tema 3 subtema 2 yang akan dibuat serta pengujian validasi terhadap media board game ular tangga yang akan dikembangkan. Rancangan tersebut dikembangkan dengan langkah-langkah seperti dibawah berikut ini: 
1. Penulis merancang media board game ular tangga. Perancangan media ini disesuaikan dengan materi yang akan dibahas dan kebutuhan peneliti serta memperhatikan spesifikasi sebagai berikut:

a. Bentuk media board game ular tangga yang terdiri atas $\mathrm{KI}, \mathrm{KD}$, dan tujuan pembelajaran, serta penunjang media tersebut seperti dadu ular tangga dan alat untuk memaikannya serta soal yang harus di jawab setiap nomor yang sudah disiapkan.

b. Di desain dengan menerapkan unsur-unsur tentang metamorfosis kupu-kupu, dan dimasukkan gambar-gambar terkait unsur materi metamorfosis kupu-kupu.

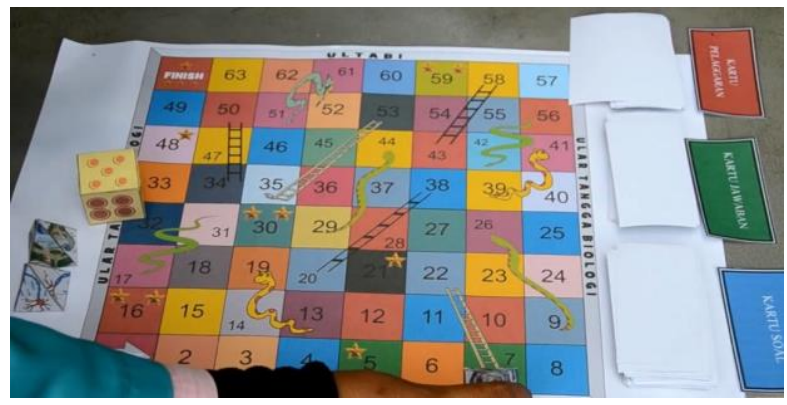

Gambar 2. Tampilan media board game ular tangga

2. Memvalidasikan media board game ular tangga kepada ahli materi dan ahli media. Media board game ular tangga harus dinyatakan valid dan layak oleh ahli-ahli tersebut. Data hasil evaluasi dari ahli materi dan ahli desain selanjutnya dianalisis untuk mengetahui tingkat kevalidan media board game ular tangga dan revisi yang perlu dilakukan berdasarkan masukkan dan saran dari ahli-ahli tersebut. Produk media board game ular tangga materi metamorfosis kupu-kupuini di validasikan oleh 4 validator. Berikut nama-nama yang menjadi validator media tersebut yaitu:

a. Benni Handayani, M. I. Kom. selaku Dosen Fakultas Ilmu Komunikasi Universitas Islam Riau (Validator ahli media 1)

b. Ivan Taufiq, M. I. Kom. selaku Dosen Fakultas Ilmu Komunikasi Universitas Islam Riau (Validator ahli media 2)

c. Exmela Dona, S. Pd. selakukepala sekolah di Sekolah Dasar Negeri 104 Pekanbaru (Validator ahli materi 1)

d. Jannah Sulaiman, S. Pd. selaku guru kelas IV di Sekolah Dasar Negeri 169 Pekanbaru (Validator ahli materi 2)

Pada tahap revisi ini, meliputi masukkan dan saran dari validator ahli media dan ahli materi yang dilakukan guna menyempurnakan produk berupa media board game ular tangga tema 3 subtema 2 yang dikembangkan agar menjadi lebih baik. 
Tahap revisi awal, peneliti melakukan validasi ahli media, ini dilakukan oleh dua orang validator yaitu Bapak Benni Handayani M. I. Kom. (Dosen Fakultas Ilmu Komunikasi Universitas Islam Riau) dan Bapak Ivan taufiq M. I. Kom. (Dosen Fakultas Ilmu Komunikasi Universitas Islam Riau). Ahli media memberikan penilaian terhadap aspek tampilan media board game ular tangga pada materi metamorfosis kupu-kupu tema 3 subtema 2 kelas IV. Adapun hasil penelitian terhadap produk aspek media board game ular tangga dapat dilihat dalam tabel 2 sebagai berikut:

Tabel 2. Hasil Validasi Pertama Ahli Media

\begin{tabular}{lcccc}
\hline Validator & $\begin{array}{c}\text { Skor } \\
\text { Empiris }\end{array}$ & $\begin{array}{c}\text { Skor } \\
\text { maksimal }\end{array}$ & Persentase & Kategori \\
\hline Benni Handayani & 55 & 60 & $91 \%$ & Sangat Valid \\
Ivan Taufiq & 56 & 60 & $93 \%$ & Sangat Valid \\
Nilai Gabungan & 111 & 120 & $92 \%$ & Sangat Valid
\end{tabular}

(Sumber: Data Olahan Peneliti)

Tabel di atas adalah hasil uji validasi pada aspek media terhadap produk media board game ular tangga tema 3 subtema 2 oleh ahli media terhadap produk media board game ular tangga tema 3 subtema 2. Dari hasil validasi pertama validator media 1 yang dilakukan oleh bapak Benni Handayani mendapatkan skor empiris atau skor yang diperoleh oleh produk sebesar 55 dari skor maksimal yaitu 60, maka mendapatkan nilai sebesar 91\% dengan kategori sangat valid. Validator media 2 yang dilakukan oleh bapak Ivan Taufiq mendapatkan skor empiris atau skor yang diperoleh oleh produk sebesar 56 dari skor maksimal yaitu 60, maka mendapatkan nilai sebesar 93\% dengan kategori sangat valid, sehingga diperoleh nilai rata-rata dari kedua ahli sebesar $92 \%$ yang termasuk ke dalam kategori "Sangat Valid".

Peneliti melakukan validasi pada tanggal 30 Juli Agustus 2012 dengan Bapak Benni Handayani M. I. Kom. selaku validator 1 memberikan saran dan masukkan agar bahannya di ganti dengan yang lebih tahan lama dan lebih elegan. Selanjutnya peneliti juga melakukan validasi pertama pada media pada tanggal 02 Agustus 2021 dengan Bapak Ivan Taufiq M. I. Kom. selaku validator 2 memberikan masukkan dan saran yaitu agar menggunakan huruf yang lebih jelas dalam konteks media pembelajaran.

Setelah media board game direvisi dengan saran dan masukkan yang diperoleh dari hasil validasi pertama, maka selanjutnya dilakukan validasi kedua. Adapun hasil validasi kedua pada tabel 3 sebagai berikut:

Tabel 3. Hasil Validasi Revisi Ahli Media 


\begin{tabular}{ccccc}
\hline Validator & $\begin{array}{c}\text { Skor } \\
\text { Empiris }\end{array}$ & $\begin{array}{c}\text { Skor } \\
\text { Maksimal }\end{array}$ & Persentase & Kategori \\
\hline Benni Handayani & 57 & 60 & $95 \%$ & Sangat Valid \\
Ivan Taufiq & 60 & 60 & $100 \%$ & Sangat Valid \\
Nilai Gabungan & 117 & 120 & $97,5 \%$ & Sangat Valid \\
\hline
\end{tabular}

Pada tabel 3 di atas merupakan hasil penilaian oleh ahli media terhadap produk media board game ular tangga pada tahap kedua. Setelah media board game ular tangga diperbaiki sesuai dengan saran dan masukkan pada validasi pertama, selanjurnya peneliti melakukan tahap validasi kedua. Adapun hasil validasi kedua oleh bapak Benni Handayani M. I. Kom. pada tanggal 05 Agustus 2021 mendapat hasil bahwa media pembelajaran yang dikembangkan sudah dapat digunakan tanpa revisi. Hasil validasi kedua oleh bapak Ivan Taufiq M. I. Kom. pada tanggal 05 Agustus 2021 mendapat hasil bahwa media pembelajaran sudah menarik dan bagus untuk digunakan sebagai media pembelajaran bagi siswa kelas IV sekolah dasar. Hasil validasi tampilan media board game ular tangga pada validasi kedua yang diperoleh validasi kedua validator media 1 mendapatkan skor empiris atau skor yang diperoleh oleh produk sebesar 57 dari skor maksimal yaitu 60, maka mendapatkan nilai sebesar 95\% dengan kategori sangat valid. Validator media 2 mendapatkan skor empiris atau skor yang diperoleh oleh produk sebesar 60 dari skor maksimal yaitu 60, maka mendapatkan nilai sebesar 100\%, sehingga dari gabungan dua validator termasuk kreteria sangat valid dengan rata-rata persentase $97.5 \%$ dengan kategori sangat valid. Pada hasil tahap validasi kedua, maka peneliti mendapatkan peningkatan nilai sebanyak 5,01\% dibandingkan dari hasil validasi pertama. Peningkatan ini didapatkan setelah peneliti melakukan revisi sesuai saran dan komentar dari validator yang bersangkutan.

Pada tahap validasi selanjutnya dilakukan oleh ahli materi, yaitu dua validator terdiri atas Ibu Jannah Sulaiman, S. Pd. selaku Kepala Sekolah di SDN 104 Pekanbaru dan Ibu Exmela Dona, S. Pd. selaku guru kelas IV di SDN 169 Pekanbaru. Ahli materi memberikan penilaian terhadap aspek materi dalam produk media board game ular tangga tema 3 subtema 2 di kelas IV. Adapun hasil kelayakan oleh ahli materi pada tabel 4 sebagai berikut:

Tabel 4. Hasil Validasi Pertama Ahli Materi

\begin{tabular}{ccccc}
\hline Validator & Skor Empiris & $\begin{array}{c}\text { Skor } \\
\text { Maksimal }\end{array}$ & Persentase & Kategori \\
\hline Exmela Dona & 26 & 32 & $81,25 \%$ & Cukup valid
\end{tabular}


PENGEMBANGAN MEDIA BOARD GAME ULAR TANGGA PADA MATERI METAMORFOSIS ...

Uswatun Hidayah, Siti Quratul Ain

$\begin{array}{lllll}\text { Jannah Sulaiman } & 29 & 32 & 90,6 \% & \text { Sangat valid } \\ \text { Nilai gabungan } & 55 & 64 & 85,93 \% & \text { Cukup valid }\end{array}$

(Sumber: Data Olahan Peneliti)

Berdasarkan tabel $4 \mathrm{di}$ atas hasil peneliti ahli materi pada validasi pertama terhadap produk media board game ular tangga tema 3 subtema 2 di kelas IV. Adapun perolehan nilai dari validator materi 1 mendapatkan skor empiris atau skor yang diperoleh oleh produk sebesar 26 dari skor maksimal 32, maka mendapatkan nilai sebesar 81,25\% dengan kategori cukup valid. Validator media 2 mendapatkan skor empiris atau skor yang diperoleh oleh produk sebesar 29 dari skor maksimal 32, maka mendapatkan nilai sebesar 90,6\% dengan kategori sangat valid, sehingga diperoleh nilai ratarata dari kedua ahli materi sebesar $85,93 \%$ yang termasuk ke dalam kategori "Sangat Valid". Peneliti melakukan validasi pertama bersama Ibu Exmela Dona, S. Pd. pada tanggal 12 Agustus dan mendapati saran dan komentar bahwa soal yang diberikan harus lebih fokus kepada materi yang diajarkan agar siswa lebih mudah dipahami oleh siswa. Selanjutnya peneliti melakukan validasi kedua pada tanggal 16 agustus 2021 dengan Ibu Jannah Sulaiman, S. Pd. selaku validator kedua. Adapun saran dan komentarnya, yaitu 1) dilengkapi komponen penilaian lembar validasinya, 2) media board game ular tanga sangat menarik.

Selanjutnya diperbaiki dengan saran dan masukkan dari validasi pertama selanjutnya dilanjutkan dengan validasi kedua. Hasil validasi kedua dapat dilihat pada tabel 5 sebagai berikut:

Tabel 5. Hasil Validasi Revisi Ahli Materi

\begin{tabular}{lcccc}
\hline \multicolumn{1}{c}{ Validator } & $\begin{array}{c}\text { Skor } \\
\text { Empiris }\end{array}$ & Skor maksimal & Persentase & Kategori \\
\hline Exmela Dona & 30 & 32 & $93,75 \%$ & Sangat Valid \\
Jannah Sulaiman & 31 & 32 & $96,87 \%$ & Sangat Valid \\
Nilai Gabungan & 61 & 64 & $95,29 \%$ & Sangat valid \\
\hline
\end{tabular}

(Sumber: Data Olahan Peneliti)

Pada tabel 5 di atas merupakan hasil penilaian ahli materi tehadap produk media board game ular tangga validasi kedua. Adapun perolehan nilai dari validator materi 1 mendapatkan nilai sebesar 93,75\% dengan kategori sangat valid dan validator media 2 mendapatkan nilai sebesar 96,87\% dengan kategori sangat valid, sehingga memperoleh rata-rata persentase dari kedua ahli materi sebesar 95,29\% dengan kategori sangat valid. Pada hasil tahap validasi kedua, peneliti mendapatkan selisih nilai sebanyak 9,36\% dibandingkan dari hasil validasi pertama. Peningkatan ini didapatkan setelah peneliti melakukan revisi sesuai saran dan komentar dari validator yang bersangkutan. Setelah media board game ular tangga diperbaiki sesuai dengan saran dan masukkan validasi pertama 
selanjutnya melakukan validasi kedua oleh Ibu Exmela Dona, S. Pd. pada tanggal 19 Agustus 2021 mendapatkan hasil bahwa media board game ular tangga sudah efektif digunakan dalam pembelajaran di kelas materi metamorfosis kupu-kupu. Pada validasi kedua oleh Ibu Jannah Sulaiman, S. Pd. mendapatkan hasil bahwa media board game ular tangga layak digunakan ditingkat kelas IV SD dalam materi metamorfosis kupu-kupu pada tema 3 subtema 2.

Setelah validasi terhadap produk media board game ular tangga pada materi metamorfosis kupu-kupu tema 3 subtema 2 kelas IV telah selesai dilakukan oleh peneliti dan merevisi produk sesuai dengan saran dari validator, maka peneliti menggabungkan keseluruhan nilai yang telah diperoleh oleh masing-masing validator yang bersangkutan baik dari validator media maupun validator materi. Adapun keseluruhan nilai yang diperoleh peneliti dapat dilihat pada tabel dibawah ini:

Tabel 6. Hasil Validasi Keseluruhan

\begin{tabular}{lcc}
\hline \multirow{2}{*}{$\begin{array}{c}\text { Aspek yang } \\
\text { Dinilai }\end{array}$} & \multicolumn{2}{c}{ Persentase Validasi (\%) } \\
\cline { 2 - 3 } & I & II \\
\hline Format Media & $92 \%$ & $97,5 \%$ \\
Format Materi & $85,93 \%$ & $95,29 \%$ \\
Rata-rata & $89.21 \%$ & $96,39 \%$ \\
\hline
\end{tabular}

Berdasarkan tabel 6 di atas dapat dilihat hasil validasi oleh produk media board game ular tangga tema 3 subtema 2, seluruh hasil validasi dari keseluruhan aspek media pembelajaran board game ular tangga, yaitu ahli materi dan ahli desain yang diperoleh dari 4 validator untuk dua kali validasi. Pada validasi pertama memperoleh 92\% dengan kategori sangat valid sedangkan validasi kedua memperoleh 97,5\% dengan kategori sangat valid, maka dari validasi yang telah dilakukan produk media mendapatkan peningkatan persentase sebanyak 5,01\%. Selanjutnya validasi oleh ahli materi pada validasi pertama memperoleh $85 \%$ dengan kategori cukup valid, sedangkan validasi kedua memperoleh 95\% dengan kategori sangat valid, sehingga produk media juga mendapatkan peningkatan persentase sebanyak 9,36\%. Adapun hasil dari penilaian terhadap produk media pembelajaran board game memperoleh nilai rata-rata validasi pertama oleh ahli media dan ahli materi diperoleh sebanyak 89,21\%, sedangkan rata-rata validasi kedua oleh ahli media dan ahli materi mendapatkan nilai persentase sebesar 96,31\%, sehingga dengan kata lain dapat dikatakan penilaianproduk media pembelajaran board game mendapatkan peningkatan sebanyak $7,18 \%$. 
Adapun hasil penelitian seluruh aspek terhadap produk media board game ular tangga pada materi metamorfosis kupu-kupu tema 3 subtema 2 kelas IV terdiri dari ahli media dan ahli materi pada validasi pertama dan validasi kedua dapat disajikan dalam bentuk diagram seperti dibawah ini.

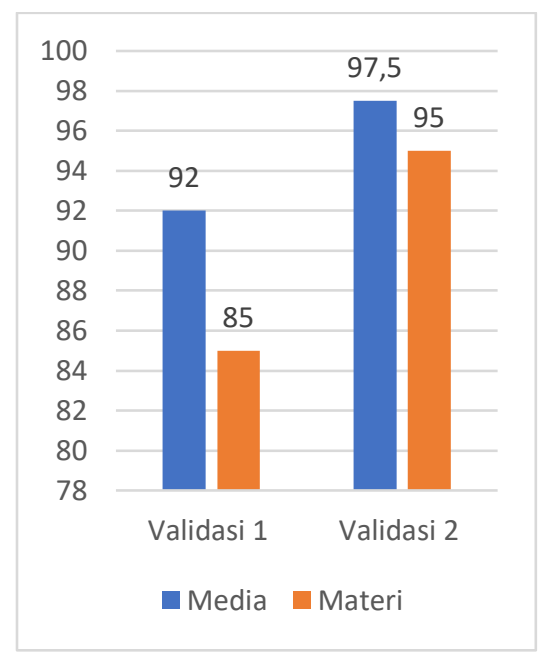

Gambar 3. Diagram Penilaian Aspek Keseluruhan Media

Berdasarkan diagram di atas dapat dikatakan bahwa hasil penelitian format media dan format materi terhadap produk media pembelajaran board game ular tangga yang disajikan terlihat kenaikan perolehan nilai pada validasi pertama dan kedua dari format media sebesar 5,5\%, sedangkan pada validasi materi dari validasi pertama dan kedua memperoleh kenaikan signifikan sebesar $10 \%$. Perbandingan hasil persentase validasi pertama dan kedua dapat dilihat dalam bentuk diagram seperti dibawah ini.

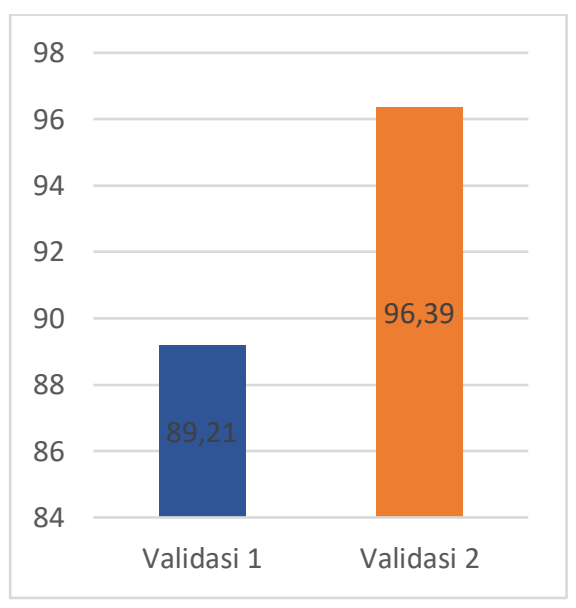

Gambar 4. Diagram Perbandingan Hasil Penilaian Media Board Game Ular Tangga

Dari gambar di atas dapat dilihat bahwa terjadi peningkatan yang signifikan dari validasi pertama ke validasi kedua sebanyak $7,18 \%$. Pada validasi pertama terhadap produk media board game ular tangga memperoleh nilai dari validator ahli media dan ahli materi dengan rata-rata 
persentase $89.21 \%$ sedangkan validasi kedua terhadap produk media board game ular tangga memperoleh nilai dari validator ahli media dan ahli materi dengan rata-rata persentase 96,39\% sehingga rata-rata persentase yang diperoleh oleh produk media board game ular tangga pada materi metamorfosis kupu-kupu tema 3 subtema 2 kelas IV adalah 92,8\%.

Berdasarkan pembahasan dan hasil penelitian yang telah dilakukan oleh peneliti, dapat disimpulkan bahwa produk media pembelajaran media board game ular tangga pada materi metamorfosis kupu-kupu untuk siswa kelas IV dapat dikatakan sangat layak.

\section{KESIMPULAN}

Berdasarkan hasil penlitian pengembangan media pembelajaran media board game ular tangga pada materi metamorfosis kupu-kupu dengan tema 3 subtema 2 di kelas IV, dapat ditarik kesimpulan bahwa pengembangan media board game ular tangga didasari oleh model pengembangan. Adapun tahapan dalam pengembangan media pembelajaran tersebut dimulai dari pengumpulan informasi yang didapatkan melalui kegiatan wawancara dengan guru kelas IV, kemudian merancang desain media board game ular tangga dengan menggunakan laptop. Setelah selesai produk dilanjutkan dengan tahap validasi media board game ular tangga.

Adapun penilaian terhadap produk media board game ular tangga pada materi metamorfosis kupu-kupu yang dikembangkan oleh 2 ahli yaitu ahli media dan ahli materi dengan memenuhi kriteria kevalidan. Tingkat kevalidan untuk ahli media sebesar 89,21\%, sedangkan materi mendapatkan skor sebesar 96,39\%. Dengan demikian mendapatkan rata-rata kevalidan sebesar 92,8\%. Berdasarkan persentase tersebut dapat disimpulkan bahwa media pembelajaran valid untuk digunakan pada materi metamorfosis kupu-kupu tema 3 subtema 2 kelas IV.

\section{DAFTAR PUSTAKA}

Akbar, Sa'dun. (2013). Instrumen Perangkat Pembelajaran. Bandung : PT Remaja Rosdakarya.

Alfasyi, M. c. (2015). Pengaruh penggunaan media video terhadap hasil belajar IPA siswa kelas IV SD Negeri Ngoto Bantul Yogyakarta. Basic Education, 4.

Arsyad, A. (2014). media pembelajaran. jakarta: raja grafindo persada.

Atiaturrahmaniah, d. (2017). Pengembangan Matematika SD. Selong: Universitas Hamzawandi Press. 
Dea Mustika, F. D. (2020). Peningkatan Kreativitas Mahasiswa Dalam Pembuatan Alat Peraga IPA Menggunakan Pembelajaran Berbasis Proyek. SALIHA: Jurnal Pendidikan \& Agama Islam, $31-48$.

Desri, M., \& Solihatulmilah, E. (2019). Permainan Ular Tangga Dalam Mengingkatkan Kemampuan Moral Anak. Jurnal Petik, 5(1), 85-91.

Gazali, R. Y. (2016). pembelajaran matematika yang bermakna. jurnal pendidikan matematika, 181190.

Giyanti. (2018). Pengembangan Media Pembelajaran Pop-Up Book Untuk Peserta Didik TunaRungu SMP-LB Pada Materi Gerak dan Gaya. Skripsi. Fakultas Tarbiyah dan Keguruan.

Imaliyah, D. A. (2018). Pengembangan media pembelajaran ular tangga untuk meningkatkan motivasi belajar siswa kelas VIII tema "Perubahan Masyarakat Indonesia pada masa penjajahan dan tumbuhnya semangat Kebangsaan” mata pelajaran IPS di SMP Muhammadiyah 15 Lamongan (Doctoral dissertation, Universitas Islam Negeri Maulana Malik Ibrahim).

Isnaeni, N., \& Hildayah, D. (2020). Media Pembelajaran Dalam Pembentukan Interaksi Belajar Siswa. Jurnal Syntax Transformation, 1(5), 148-156.

Jalius, Nizwar dan Ambiyar. 2016. Media Sumber Pembelajaran. Kencana Jakarta

Karimah, R. F., Supurwoko, S., \& Wahyuningsih, D. (2014). Pengembangan media pembelajaran ular tangga fisika untuk siswa SMP/MTs kelas VIII. Jurnal Pendidikan Fisika, 2(1).

Komara, Endang. (2014). Belajar dan Pembelajaran, Refika Aditama: Bandung

Musa'adah, N. (2017). Pengembangan Media Ular Tangga Pembelajaran Ipa Materi Perubahan Lingkungan Kelas Iv SDN Demaan Rembang (Doctoral dissertation, Universitas Negeri Semarang).

Mustika, D., Dafit, F., \& Sinthya, V. (2020). Peningkatan Kreativitas Mahasiswa Dalam Pembuatan Alat Peraga IPA Menggunakan Pembelajaran Berbasis Proyek. SALIHA: Jurnal Pendidikan \& Agama Islam, 3(1), 31-48

Purnama, S. (2016). Metode penelitian dan pengembangan (pengenalan untuk mengembangkan produk pembelajaran bahasa Arab). LITERASI (Jurnal Ilmu Pendidikan), 4(1), 19-32.

Rusman, dkk. (2013). Pembelajaran Berbasis Teknologi Komunikasi dan Komunikasi Mengembangkan Profesional Guru. PT Raja Grafindo: Jakarta 
Saefudin, Asis. (2014). Pembelajaran Efektif, Remaja Rosdakarya : Bandung

Safitri, H. (2019). Pengembangan Media Pembelajaran Permainan Ular Tangga Pada Mata Pelajaran Marketing Kompetensi Dasar Menganalisis Segmentasi Pasar di Kelas X Bisnis Daring dan Pemasaran SMK Negeri 1 Lamongan. Jurnal Pendidikan Tata Niaga (JPTN), 7(2).

Septiria, D. (2020). Perkembangan Sosial Emosional Anak Kelompok Bermain Melalui Alat Permainan Edukatif Magic Box (Doctoral dissertation, IAIN BENGKULU).

Simanjuntak, M. M. P. (2018). Pengembangan Board Game Edukasi Dengan Teknologi Augmented Reality (Studi Kasus Permainan Ular Tangga) (Doctoral dissertation, Universitas Brawijaya).

Sugiyono. (2019). Metode Penelitian Pendidikan (Pendekatan Kuantitatif, Kualitatif dan R\&D). Bandung: Alfabeta.

Sukardjo. (2015). Landasan Pendidikan Konsep dan Aplikasinya. Jakarta:PT Rajagrafindo Persada.

Suryani, N. (2018). Media Pembelajaran Inovatif dan dan Pengembangannya. Bandung: PT Remaja Rosdakarya.

Tafonao, T. (2018). Peranan media pembelajaran dalam meningkatkan minat belajar mahasiswa. Jurnal Komunikasi Pendidikan, 2(2), 103-114.

UU Nomor 20 Tahun 2003 pasal 1 ayat 1 tentang Sistem pendidikan nasional. Departemen Pendidikan Nasional: Jakarta 
PENGEMBANGAN MEDIA BOARD GAME ULAR TANGGA PADA MATERI METAMORFOSIS ...

Uswatun Hidayah, Siti Quratul Ain 